Article

\title{
Modeling and Analysis of Transport Processes and Efficiency of Combined SOFC and PEMFC Systems
}

\author{
Abid Rabbani and Masoud Rokni * \\ Department of Mechanical Engineering, Thermal Energy System, Technical University of Denmark, \\ Building 403, 2800 Kgs Lyngby, Denmark; E-Mail: abid.rabbani@gmail.com \\ * Author to whom correspondence should be addressed; E-Mail: MR@mek.dtu.dk; \\ Tel.: +45-4525-4124; Fax: +45-4593-5215.
}

Received: 20 May 2014; in revised form: 12 August 2014 / Accepted: 19 August 2014 /

Published: 25 August 2014

\begin{abstract}
A hybrid fuel cell system $(\sim 10 \mathrm{kWe})$ for an average family house including heating is proposed. The investigated system comprises a Solid Oxide Fuel Cell (SOFC) on top of a Polymer Electrolyte Fuel Cell (PEFC). Hydrogen produced from the off-gases of the SOFC can be fed directly to the PEFC. Simulations for the proposed system were conducted using different fuels. Here, results for natural gas (NG), dimethyl ether (DME) and ethanol as a fuel are presented and analysed. Behaviour of the proposed system is further investigated by comparing the effects of key factors such as utilisation factor, operating conditions, oxygen-to-carbon $(\mathrm{O} / \mathrm{C})$ ratios and fuel preheating effects on these fuels. The combined system improves the overall electrical conversion efficiency compared with standalone PEFC or SOFC systems. For the combined SOFC and PEFC system, the overall power production was increased by $8 \%-16 \%$ and the system efficiency with one of the fuels is found to be $12 \%$ higher than that of the standalone SOFC system.
\end{abstract}

Keywords: Solid Oxide Fuel Cell (SOFC); Proton Exchange Membrane Fuel Cell (PEMFC); fuel cell; hybrid systems; system efficiency; multi-fuel

\section{Introduction}

High temperature fuel cells have shown significant potential as a viable solution for power production. The Solid Oxide Fuel Cells (SOFC) system is the most mature of the many options. It operates in the range of $750-1000{ }^{\circ} \mathrm{C}$, which allows it to combine with other conventional thermal 
cycles to further enhance the thermal efficiency [1]. The hybrid SOFC system is considered to be a key technology in achieving the goals of the future on account of the many advantages it offers over other systems.

Firstly, SOFCs do not contain any moving parts. Noise and vibrations during operation are practically non-existent, making it possible to install the systems in urban areas. The lack of mechanical parts also assures high reliability and low maintenance costs. Secondly, SOFCs can operate on a variety of fuels and are more resistant to electrode poisoning. They can tolerate sulphur compounds at concentrations higher than other types of fuel cells [2]. In addition, unlike most fuel cells, CO can be used as a fuel in SOFC. Due to the abovementioned advantages, SOFCs are considered a strong candidate for hybrid systems or integration into currently deployed technologies. On the other hand, polymer electrolyte fuel cells also possess desirable properties in low temperature domains. Due to their low temperature operation, no internal reforming can take place and only pure hydrogen can be used as a fuel.

SOFC-based hybrid power plants have been proposed by researchers in extensive studies on integration of SOFCs in gas turbine (GT) and steam turbine (ST) power plants [3-5], along with a few on SOFC-Stirling hybrid systems [6,7], whereas studies on prospects of combining SOFC with a Polymer Electrolyte Fuel Cell (PEFC) are relatively limited [8-11]. Although, SOFC-GT and SOFC-ST power plants display high efficiencies when compared to conventional combined cycles, their operations are limited to large-scale plants only. Combined SOFC-PEFC plants offer a viable potential for small-scale Combined Heat and Power (CHP) generation units due to the fact that they have rapid start-up times. However, the capital cost of SOFCs and PEFCs turns out to be the major obstacle in commercialization of these plants. This study is an effort to investigate the feasibility of a small-scale SOFC-PEFC power plant.

Hybrid systems that comprise a SOFC combined with a PEFC have been described in the literature. In these systems, the internal reforming ability of the SOFC is utilized by the PEFC to produce hydrogen. The heat released from electrochemical reactions in the SOFC is consumed in the reforming process. The exhaust stream is directed to the shift reactors, where the CO reacts with $\mathrm{H}_{2} \mathrm{O}$ to produce $\mathrm{CO}_{2}$ and $\mathrm{H}_{2}$. The remaining traces of $\mathrm{CO}$ are removed by selective catalytic oxidation. According to [11], overall conversion efficiency was found to be around $10 \%$ higher than that of a standalone SOFC system.

SOFC-PEFC systems that are connected in series are reported in [12]. Using this configuration, the gas mixture fed to the cathode of the SOFC contains some water. The efficiency of the SOFC-PEFC combination as predicted by simulations is about $60 \%$ [13]. In studies conducted by Dick et al. [8], it is established that the efficiency of SOFC-PEFC decreases with increasing operating pressures. Yokoo et al. $[13,14]$ also presented a parallel fuel feeding configuration in which the reformed gas was separated into two flow streams for the SOFC and the PEFC. In this parallel configuration, the PEFC is fuelled from the reformer directly (unlike the serial configuration which uses depleted fuel from the SOFC anode). According to these studies, a 5\% efficiency improvement was obtained using natural gas as fuel with a parallel SOFC-PEFC system, as compared with the stand-alone SOFC.

Most of the studies on combined SOFC-PEFC systems have either highlighted the use of a combined reformer for both the SOFC and PEFC, or elaborated the use of exhaust heat from the SOFC to produce hydrogen. These systems are somewhat complex and heat management poses a 
considerable threat to stable plant operations. However, in the present study a simplified system is proposed in which hydrogen from the SOFC off-gas is extracted by a purifying membrane, eliminating the use of several complex reactors. Additionally, this system can handle different fuels with little or no modification. It should also be noted that the system presented here was studied thermodynamically and the objective of this study was not to present or discuss associated costs.

\section{Methodology}

The results of this paper are obtained using the Dynamic Network Analysis (DNA) simulation tool [15], which is a tool for energy system analysis. It is the latest result of on-going development at the Department of Mechanical Engineering, Technical University of Denmark, which began with a Master's Thesis work in 1989. Since then the program has been developed to be generally applicable while providing unique features, and hence supplementing other simulation programs.

In DNA, the physical model is formulated by connecting the relevant component models through nodes and by including operating conditions for the complete system. The physical model is converted into a set of mathematical equations to be solved numerically. The mathematical equations include mass and energy balances for all components and nodes as well as relations for thermodynamic properties of the fluids involved. During the development of DNA, the four key terms of portability, robustness, efficiency, and flexibility were kept in mind as the important features for making it a generally applicable tool for energy system studies. The program is written in FORTRAN. Over the years a library with different fuels such as NG, methanol, ethanol, dimethyl ether (DME), ammonia, etc., and their thermodynamic properties has been implemented.

\subsection{Modeling of SOFC Stacks}

The SOFC model developed in this investigation is based on the planar type developed by DTU-Risø and TOPSØE Fuel Cell (TOFC). The model was calibrated in the $650{ }^{\circ} \mathrm{C}$ to $800{ }^{\circ} \mathrm{C}$ (operating temperature) range against experimental data as described in $[5,16]$, but to clarify how it is implemented in the in-house program, it is briefly explained here. The operational voltage $\left(E_{F C}\right)$ was found to be:

$$
E_{F C}=E_{\text {Nernst }}-\Delta E_{\text {act }}-\Delta E_{\text {ohm }}-\Delta E_{\text {conc }}-\Delta E_{\text {offset }}
$$

where $E_{\text {Nernst }}, \Delta E_{\text {act }}, \Delta E_{\text {ohm }}, \Delta E_{\text {conc }}$ and $\Delta E_{\text {offset }}$ are the Nernst ideal reversible voltage (open voltage circuit), activation polarization, ohmic polarization, concentration polarization and the offset polarization, respectively.

The offset polarization is neglected and the Nernst reversible voltage is given by [17]:

$$
E_{\text {Nernst }}=\frac{-\Delta \bar{g}_{f}^{0}}{n_{e} \mathrm{~F}}+\frac{\mathrm{R} T}{n_{e} \mathrm{~F}} \ln \left(\frac{p_{\mathrm{H}_{2}, \text { tot }} \sqrt{p_{\mathrm{O}_{2}}}}{p_{\mathrm{H}_{2} \mathrm{O}}}\right)
$$

where $\mathrm{R}, \mathrm{F}$ and ne are the universal gas constant, Faraday constant and $n_{e}$ is the number of electrons transferred in the cell reaction, respectively. The partial pressures were assumed to be the average between the inlet and outlet weighted by molar fraction $(y)$ for anode and cathode separately as: 


$$
\begin{aligned}
& p_{j}=\left(\frac{y_{j, \text { out }}-y_{j, \text { in }}}{2}\right) p_{\text {anode }} \quad j=\left\{\mathrm{H}_{2}, \mathrm{CO}, \mathrm{CH}_{4}, \mathrm{CO}_{2}, \mathrm{H}_{2} \mathrm{O}, \mathrm{N}_{2}\right\} \\
& p_{\mathrm{O}_{2}}=\left(\frac{y_{\mathrm{O}_{2}, \text { out }}-y_{\mathrm{O}_{2}, \text { in }}}{2}\right) p_{\text {cathode }}
\end{aligned}
$$

Thus the effect of partial pressures on the Nernst equation is neglected. The change in standard Gibbs free energy $\left(\Delta \bar{g}_{f}{ }^{0}\right)$ is and the number of electrons transferred for each molecule of fuel $\left(n_{e}=2\right)$ and calculated by:

$$
\Delta \bar{g}_{f}^{0}=\left(\bar{g}_{f}^{0}\right)_{\mathrm{H}_{2} \mathrm{O}}-\left(\bar{g}_{f}^{0}\right)_{\mathrm{H}_{2}}-\frac{1}{2}\left(\bar{g}_{f}^{0}\right)_{\mathrm{O}_{2}}
$$

The activation polarization was evaluated from the Butler-Volmer equation [18] by isolating it from other polarizations to determine the charge transfer coefficients and exchange current density from the experiment by the curve fitting technique:

$$
\Delta E_{a c t}=\frac{\mathrm{R} T}{(0.001698 T-1.254) \mathrm{F}} \sinh ^{-1}\left[\frac{i_{d}}{2\left(13.087 T-1.096 \times 10^{4}\right)}\right]
$$

where $i_{d}$ is the current density.

The ohmic polarization depends on the electrical conductivity of the electrodes as well as the ionic conductivity of the electrolyte and was expressed based on anode thickness, electrolyte thickness, cathode thickness and current density [19]:

$$
\Delta E_{o h m}=\left(\frac{t_{a n}}{\sigma_{a n}}+\frac{t_{e l}}{\sigma_{e l}}+\frac{t_{c a}}{\sigma_{c a}}\right) i_{d}
$$

where $t_{a n}=600 \mu \mathrm{m}, t_{e l}=50 \mu \mathrm{m}$ and $t_{c a}=10 \mu \mathrm{m}$ are the anode thickness, electrolyte thickness and cathode thickness, respectively, and $\sigma_{a n}, \sigma_{e l}$ and $\sigma_{c a}$ are the conductivities of the anode, electrolyte and cathode, respectively.

The concentration polarization is dominant at high current densities for anode-supported SOFCs, wherein insufficient amounts of reactants are transported to the electrodes and the voltage is then reduced significantly [20]. It was modeled as a function of the diffusion coefficient, anode limiting current and current density. The anode limiting current was modeled as function of anode porosity, anode tortuosity and a binary diffusion coefficient. Both the diffusion coefficient and the binary diffusion coefficient were calibrated against experimental data:

$$
\Delta E_{\text {conc }}=B\left(-\ln \left(1+\frac{p_{\mathrm{H}_{2}} i_{d}}{p_{\mathrm{H}_{2} \mathrm{O}} i_{a s}}\right)-\ln \left(1-\frac{i_{d}}{i_{a s}}\right)\right)
$$

where $B$ is the diffusion coefficient, which was determined using a calibration technique (see [16] for details).

Finally the current density is directly proportional to the amount of reacting hydrogen and the cell area, according to Faraday's law. The fuel composition leaving the anode was calculated by the Gibbs minimization method, as described in [21]. The power production from the SOFC $\left(P_{S O F C}\right)$ depends on 
the amount of chemical energy fed to the anode, the reversible efficiency $\left(\eta_{\text {rev }}\right)$, the voltage efficiency $\left(\eta_{v}\right)$ and the fuel utilization factor $\left(U_{F}\right)$. It is defined in mathematical form as:

$$
P_{S O F C}=\left(L H V_{H_{2}} \dot{n}_{H_{2}, i n}+L H V_{C O} \dot{n}_{C O, i n}+L H V_{C H_{4}} \dot{n}_{C H_{4}, \text { in }}\right) \eta_{r e v} \eta_{v} U_{F}
$$

where $\dot{n}$ was the molar reaction rate (molar flow), $U_{F}$ was a set value while the reversible efficiency is the maximum possible efficiency defined as the relationship between the maximum electrical energy available (change in Gibbs free energy) and the fuels LHV (lower heating value) as follows:

$$
\begin{gathered}
\eta_{\mathrm{v}}=\frac{E_{\text {cell }}}{E_{\text {Nernst }}} \\
\eta_{\text {rev }}=\frac{\left(\Delta \bar{g}_{f}\right)_{\text {fuel }}}{L H V_{\text {fuel }}} \\
\left(\Delta \bar{g}_{f}\right)_{\text {fuel }}=\left[\left(\bar{g}_{f}\right)_{\mathrm{H}_{2} \mathrm{O}}-\left(\bar{g}_{f}\right)_{\mathrm{H}_{2}}-\frac{1}{2}\left(\bar{g}_{f}\right)_{\mathrm{O}_{2}}\right] y_{\mathrm{H}_{2} \text {,in }} \\
+\left[\left(\bar{g}_{f}\right)_{\mathrm{CO}_{2}}-\left(\bar{g}_{f}\right)_{\mathrm{CO}}-\frac{1}{2}\left(\bar{g}_{f}\right)_{\mathrm{O}_{2}}\right] y_{\mathrm{CO}, \text { in }} \\
+\left[\left(\bar{g}_{f}\right)_{\mathrm{CO}_{2}}+2\left(\bar{g}_{f}\right)_{\mathrm{H}_{2} \mathrm{O}}-\left(\bar{g}_{f}\right)_{\mathrm{CH}_{4}}-2\left(\bar{g}_{f}\right)_{\mathrm{O}_{2}}\right] y_{\mathrm{CH}_{4}, \text { in }}
\end{gathered}
$$

Other alternative SOFC modelling can also be found in the literature [22-24]. For example, [22] presents SOFC modeling with parameter identification by means of impedance spectroscopy. In [23] recent developments of 3D coupled multi physics from the Julich research centre can be found.

\subsection{Modeling of PEFC}

The PEFC model applied in this investigation is based on the planar type developed by Ballard and therefore, the model was calibrated against experimental data available from this manufacturer [25]. The details can be found in the study of Hosseinzadeh and Rokni [26].

The average cell voltage of the fuel cell was defined by an analytical expression defined in Equation (1). To evaluate the activation loss, the well-known Butler-Volmer equation was used to derive the relationship between activation loss and current density. The cell total activation loss is the sum of anode and cathode contributions as:

$$
\Delta E_{\text {act }}=\frac{\mathrm{R} T}{2 \mathrm{~F}} \ln \left(\frac{i+0.002}{i_{0, \text { anode }}}\right)+\frac{\mathrm{R} T}{0.5 \mathrm{~F}} \ln \left(\frac{i+0.002}{i_{0, \text { cathode }}}\right)
$$

wherein $i_{0, \text { cathode }}=10^{-5} i_{0, \text { anode }}$ and $i_{0, \text { cathode }}$ was calibrated against experimental data and found to be:

$$
i_{0, \text { cathode }}=0.415 F \exp \left(\frac{-0.5 \mathrm{~F} E_{\text {Nernst }}}{\mathrm{R} T}\right)
$$

where R, $T$ and $\mathrm{F}$ were the universal gas constant, cell temperature and Faradays constant respectively.

The ohmic resistance was calibrated against the experimental data and found to be given by: 


$$
\Delta E_{\text {ohmic }}=0.183 \frac{170\left[1+0.03 i+0.062\left(\frac{T}{303}\right)^{2} i^{2.5}\right]}{\left(\lambda_{a v}-0.634-3 i\right) \exp [15.4(T-303) / T]} i
$$

where $i$ was the current density (set value) and $\lambda_{a v}$ was the average water content in anode and cathode sides. It was calculated based on water vapour partial pressure $\left(p_{w}\right)$ and saturated partial pressure of water $\left(p_{\text {sat }}\right)$ as:

$$
\lambda_{a \& c}=0.043+17.18\left(\frac{p_{w}}{p_{\text {sat }}}\right)-39.85\left(\frac{p_{w}}{p_{\text {sat }}}\right)^{2}+36\left(\frac{p_{w}}{p_{\text {sat }}}\right)^{3}
$$

The water content in the polymer electrolyte plays a significant role in stack lifetime and the ionic resistance of the membrane. Low humidification in the membrane causes a rapid increase in ionic resistance and high humidification will produce too much liquid water, which will overflow into the reactant channels and fill the pores in the electrodes. In order to have high ionic conductivity in the membrane it should be fully hydrated. Hydration could be achieved by the humidification of the gases, or by designing the fuel cell in a way that the water produced is allowed to hydrate the membrane [27]. Such water crossover was also applied here.

There exist alternative PEM modelling options in the literature. Analytical modelling of PEM can, for example, be found in [28], while [29] presents a thermo-mechanical study of PEM fuel cells and a comprehensive review on PEM water electrolysis is provided in [30].

\subsection{Modeling of Pre-Reformer and Methanator}

To model the pre-reformer and methanator a simple Gibbs reactor is implemented [1,31], meaning that the total Gibbs free energy reaches its minimum when chemical equilibrium is achieved. Such a characteristic can be used to calculate the outlet gas composition at a specified temperature and pressure without considering the reaction pathways. However, the species at the outlet must be specified, which can be different from a methanator and a pre-reformer. The species at the outlet of both pre-reformers are defined and as: $\mathrm{H}_{2}, \mathrm{CO}, \mathrm{CO}_{2}$, steam, $\mathrm{CH}_{4}, \mathrm{~N}_{2}, \mathrm{NO}, \mathrm{H}_{2} \mathrm{~S}, \mathrm{SO}_{2}, \mathrm{NO}_{2}, \mathrm{NH}_{3}$ and Ar. For the methanator the species at the outlet are defined as: $\mathrm{H}_{2}, \mathrm{CO}, \mathrm{CO}_{2}$, steam, $\mathrm{CH}_{4}, \mathrm{~N}_{2}, \mathrm{NO}, \mathrm{H}_{2} \mathrm{~S}$, $\mathrm{SO}_{2}, \mathrm{NO}_{2}$, hydrogen cyanide ( $\mathrm{HCN}$ ), carbonyl sulfide (COS), $\mathrm{N}_{2} \mathrm{O}, \mathrm{NO}_{3}, \mathrm{SO}_{3}$ and Ar.

\subsection{Modeling of Other Components}

The pump power consumption was calculated as:

$$
W_{\text {pump }}=\left[\frac{\dot{m} v_{\text {in }}\left(p_{\text {out }}-p_{\text {in }}\right)}{\eta}\right]_{\text {pump }}
$$

where $\dot{m}, p, v$ and $\eta$ were the mass flow, pressure, specific volume $\left(\mathrm{m}^{3} / \mathrm{kg}\right)$ and efficiency of the pump, respectively. The pump efficiency and outlet pressure were defined as shown below. The power consumption for compressors were modeled based on the definition of isentropic and mechanical efficiencies (given values) as: 


$$
\begin{gathered}
\eta_{\text {is }}=\left[\frac{h_{\text {out }, \text { Sin }}-h_{\text {in }}}{h_{\text {out }}-h_{\text {in }}}\right]_{\text {compressor }} \\
\eta_{m}=\left[\frac{\dot{m}\left(h_{\text {out }}-h_{\text {in }}\right)}{W}\right]_{\text {compressor }}
\end{gathered}
$$

where and $h_{\operatorname{Sin}}$ was the enthalpy when the entropy kept constant as for the inlet.

In modeling a heat exchanger, it was assumed that all energy from one side is transferred to the other side if heat losses were neglected, (which was also the case in this study). Depending on the type of the heat exchanger both the Logarithmic Mean Temperature Difference (LMTD) and effectiveness-Number of Transferred Unit ( $\varepsilon$-NTU) methods were used.

\section{Plant Configurations}

The proposed combined power system is constituted by a SOFC and PEFC system connected in series. The fuel is fed to the topping SOFC cycle only, where the fuel reforming and the electrochemical oxidation processes occur. The SOFC stack produces electrical power together with an exhaust stream that contains unused $\mathrm{CO}$ and $\mathrm{H}_{2}$. Instead of burning the exhaust stream in a catalytic burner straight away, $\mathrm{CO}$ and $\mathrm{H}_{2}$ from the fuel can be utilized either by water-gas shift reaction followed by a preferential oxidation or by extraction of pure $\mathrm{H}_{2}$. Here, the latter technique is selected.

Simulations for the plant are conducted using different fuels; natural gas, DME, ethanol and methanol. The configuration of SOFC plant is different depending on the nature of the fuel, whereas, the PEFC plant has the same configuration as it is only operated on pure hydrogen for all the cases. $\mathrm{H}_{2}$ is extracted by a hydrogen separator.

Two configurations are suggested for the SOFC plant; the first configuration with natural gas as fuel is shown in Figure 1a. The fuel is preheated to $200{ }^{\circ} \mathrm{C}$ in a heat exchanger before it is sent to a desulphurization unit to reduce the sulphur content in the NG. As known, SOFCs are capable of direct internal reforming of light hydrocarbons (such as methane) at the anode, but not the heavier hydrocarbons. Using a high operating temperature, methane can be directly reformed to $\mathrm{H}_{2}$ and CO. Due to small amount of heavier hydrocarbons in NG, an external reforming system is employed to avoid the thermal shock caused by the endothermic reforming reaction.

The heavier hydrocarbons in the NG are reformed in an Adiabatic Steam Reformer (ASR) type pre-reformer reactor, which is elaborated in the proceeding section. Another heat exchanger heats the fuel to the designated temperature of the pre-reformer. Due to the endothermic nature of the ASR reactions, the outlet temperature is not high enough to support direct feeding into the SOFC. In the present simulations, the temperature after the ASR reformer is found to be $469^{\circ} \mathrm{C}$. In this case, the fuel has to be pre-heated before entering into the fuel cell. The pre-reformed fuel is now sent to the anode side of the SOFC stacks. The fuel has a temperature of about $650{ }^{\circ} \mathrm{C}$ before entering the stacks. The operating temperature of the SOFC stacks is assumed to be $780{ }^{\circ} \mathrm{C}$. The thermal energy of exhaust fuel is recovered for heating the incoming fuel at all the stages mentioned above. 
Figure 1. Schematics of combined Solid Oxide Fuel Cells (SOFC)-Polymer Electrolyte Fuel Cell (PEFC) plants, (a) For natural gas (NG) as fuel with Adiabatic Steam Reformer (ASR); (b) For NG as fuel with Catalytic Partial Oxidation (CPO) and (c) For dimethyl ether (DME) and ethanol as fuels.

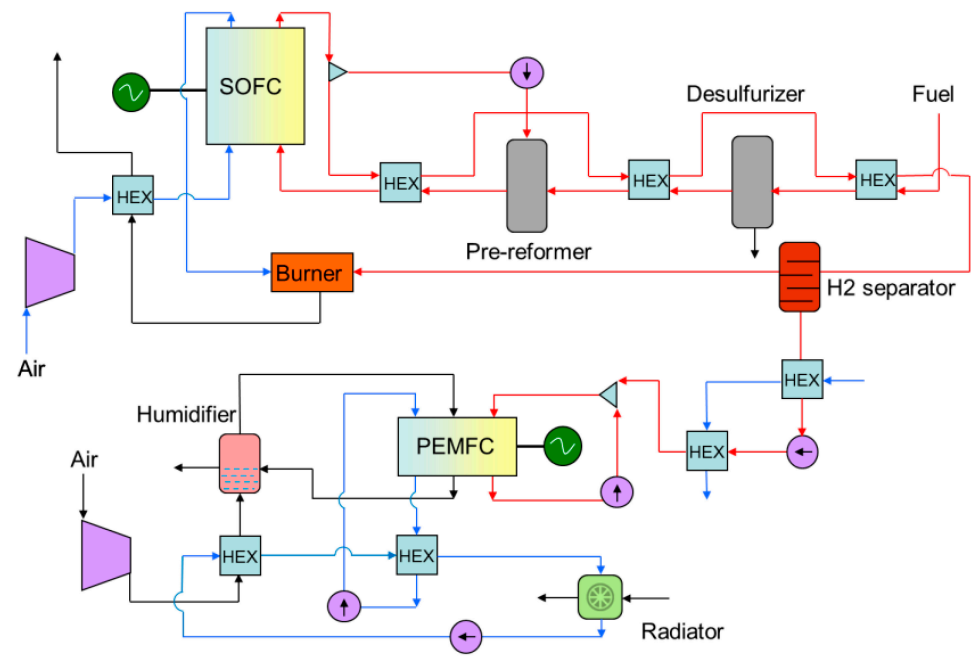

(a)

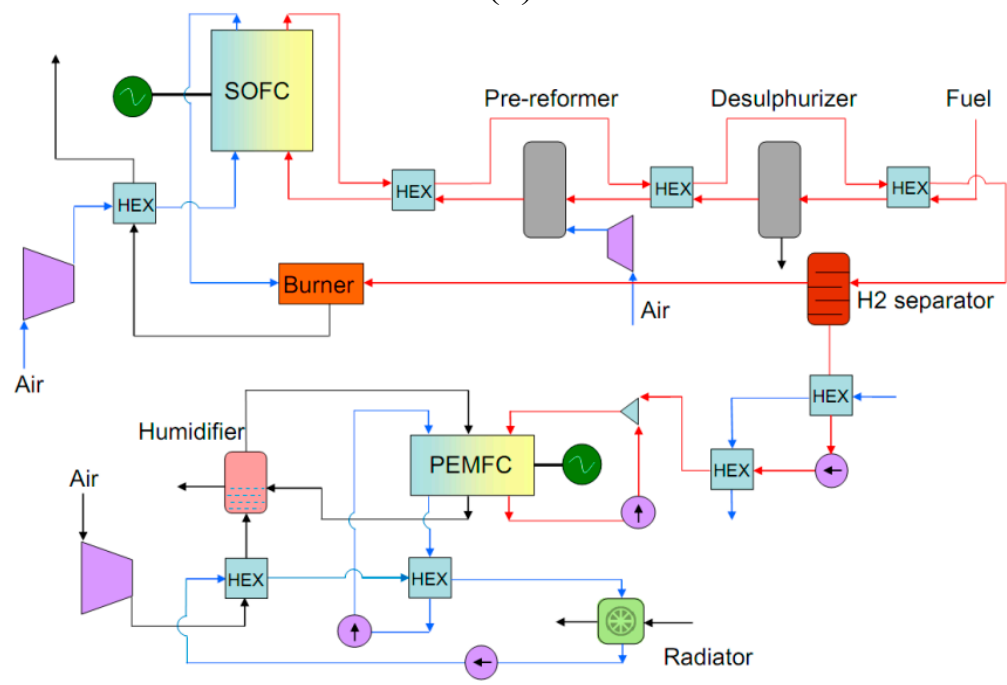

(b)

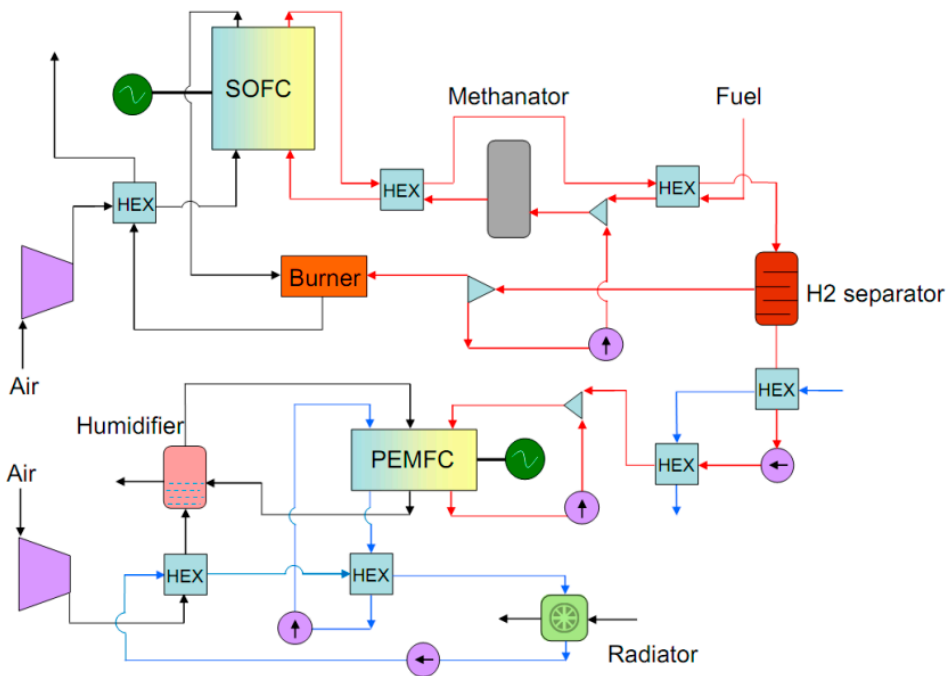

(c) 
For the cathode side of the SOFC, air is compressed in a compressor and then preheated in a recuperator to about $650{ }^{\circ} \mathrm{C}$. The electrochemical reactions at the anode and cathode produce electrical power and heat at the expense of the fuel. Part of the heat that is released is utilized in the endothermic reforming process. The depleted fuel still contains some unutilized combustible fuel, such as hydrogen and carbon monoxide. Usually, the unutilized fuel is routed to a catalytic burner for oxidation. Conversely, in the present consideration, the off-fuel stream is passed through a hydrogen separation unit before being directed to the catalytic burner. Purified hydrogen is fed to the PEFC cycle for additional power generation. This is necessary to prevent poisoning of the Pt catalysts used in the PEFC stacks. Different $\mathrm{H}_{2}$ extraction techniques are discussed in detail under its specific header.

Note that even though all $\mathrm{H}_{2}$ was recycled back to the SOFC then there will always be some $\mathrm{H}_{2}$ left in the depleted fuel due to the utilization factor. Traditionally, this off-fuel will be burned in a catalytic burner to produce heat. However, in the present embodiment all $\mathrm{H}_{2}$ is separated for the PEFC while $\mathrm{CO}$ and $\mathrm{H}_{2} \mathrm{O}$ are recycled back to the SOFC anode. It will be shown that the total plant efficiency will be thus increased compared to a stand-alone SOFC cycle including anode recirculation.

Since the extracted hydrogen is at a temperature of around $650{ }^{\circ} \mathrm{C}$, it is cooled down by a heat exchanger. It should be noted that the PEFC selected for this study operates at a higher pressure ( 2 bar) than to that of SOFC (1.1 bar). Therefore, a pump is employed for the PEFC cycle after the hydrogen cooler as seen in Figure 1a. Again the temperature of $\mathrm{H}_{2}$ increases in the pump, which is still higher than the inlet temperature for PEFC $\left(60^{\circ} \mathrm{C}\right)$. Another cooler cools it down before entering the PEFC. Water is used as a coolant for both the abovementioned heat exchangers.

The PEFC system includes a compressor, an air humidifier, set of heat exchangers and a stack which together build up the cathode circuit, the anode circuit and the cooling loop. On the cathode side, air is compressed, pre-cooled and humidified before entering the fuel cell stack at a pressure of less than 2 bar and a temperature around $60^{\circ} \mathrm{C}$. Hydrogen with a pressure of 2 bar and temperature around $60{ }^{\circ} \mathrm{C}$ enters the anode side of the stack. Since all the fuel does not react inside the stack, the rest is collected and send back to the anode stream via a recirculation pump. Compressed air passes through a humidifier which uses some of the water vapour from the cathode outlet to humidify the inlet air. The relative humidity of the air prior to PEFC stack is set to $95 \%$ in the calculations, although other values can be chosen. On the fuel side there is no humidifier and the fuel can reach the desired humidity by means of the water cross-over effect through the membrane from cathode to anode. Depending on stack power output, anode inlet humidity is between $91 \%$ and $100 \%$. These operational values are based on the fuel cell design specifications [25] and are reported to be in agreement with transient studies under different operating conditions [32,33]. For thermal management, two separate cooling circuits are used, denoted as inner and outer loops. In both loops water is used as a coolant. The inner loop is used for stack cooling and the water keeps the stack temperature around $70{ }^{\circ} \mathrm{C}$. The rejected heat from stack via coolant in the inner loop is dedicated to the water in the outer loop with working temperature around $50-60{ }^{\circ} \mathrm{C}$ and the waste heat in the outer loop is rejected through a radiator fan. For PEFC, cathode inlet pressure of 1.8 bar with hydrogen inlet pressure of 2 bar have been suggested. High anode pressure ensures that no or very less nitrogen crosses over from cathode to the anode, thereby stabilizing its operation in the long run, see [34].

The schematic of the second configuration is shown in Figure 1b. DME, ethanol and methanol are used as fuels in this configuration. Unlike natural gas, these fuels do not require any desulphurization 
unit. Also, a methanator is used for cracking the fuel and increasing the amount of methane. Due to the endothermic nature of methane reforming inside the SOFC stacks, the need for excess air to cool down the SOFC stacks will decrease. This in turn decreases the air compressor work and thereby increases the plant efficiency. The fuel is preheated before the methanator where it is reformed to $\mathrm{CH}_{4}, \mathrm{H}_{2}$ and CO. A heat exchanger heats the fuel to the desired temperature for the SOFC inlet. Some part of exhaust fuel from the SOFC is recycled and mixed with the fuel at inlet of the methanator to provide the needed steam for the methanator reactions. For the high temperature recycle pump, long term durability is a problem. On the other hand for the low temperature pump, the off-fuel stream must be cooled to a low temperature which results in wastage of substantial thermal energy. In this study, an ejector (or the high temperature recirculation pump) is employed for simulations. The rest of the plant configuration remains the same as in the NG case, see Figure $1 \mathrm{~b}$.

The main parameters for the plant are given in Table 1. The number of SOFC stacks is assumed to be 10 and number of cells per stacks is assumed to be 75 . The pressure drops in the cathode and anode sides of SOFC are assumed to be 0.05 and 0.01 bars, respectively. Since the PEFC provides a one-eighth fraction of the total power, only one stack with 25 cells would be enough in the studied system configurations. Pressure drops of 0.14 and 0.39 bar are assumed for the anode and cathode sides of the PEFC, respectively. Furthermore, the utilization factor for the SOFC cells is assumed to be 0.8 , whereas for the PEFC, stoichiometric ratios of 1.6 for $\mathrm{H}_{2}$ and 1.8 for air are used from the product datasheet of the fuel cell module [25]. The pressure drops for all heat exchangers are assumed to be 0.01 bars. As the system is designed for low-scale power, the fuel and air mass flows tend to be small, resulting in lower turbomachine efficiencies. Therefore, the compressor isentropic efficiency and mechanical efficiency are assumed to be 0.7 and 0.7 , respectively, while the generator efficiency is assumed to be 0.97 .

Table 1. Main parameters for the design point calculations in fuel cell cycles.

\begin{tabular}{ccc}
\hline Fuel Cell & SOFC & PEFC \\
\hline Compressor intake temperature, $\left({ }^{\circ} \mathrm{C}\right)$ & 25 & 25 \\
Compressor isentropic efficiency & 0.7 & 0.6 \\
Compressor mechanical efficiency & 0.7 & 0.65 \\
Cathode inlet temperature, $\left({ }^{\circ} \mathrm{C}\right)$ & 650 & 60 \\
Cathode outlet temperature, $\left({ }^{\circ} \mathrm{C}\right)$ & 780 & 68 \\
Fuel utilization factor & 0.80 & 0.62 \\
Number of cells in stack & 75 & 25 \\
Number of stacks & 10 & 1 \\
Cathode side pressure drop ratio, $($ bar $)$ & 0.05 & 0.39 \\
Anode side pressure drop ratio, $($ bar $)$ & 0.01 & 0.14 \\
Heat exchangers pressure drops, $($ bar $)$ & 0.01 & 0.01 \\
Fuel inlet temperature, $\left({ }^{\circ} \mathrm{C}\right)$ & 25 & - \\
Anode inlet temperature, $\left({ }^{\circ} \mathrm{C}\right)$ & 650 & 60 \\
Anode outlet temperature, $\left({ }^{\circ} \mathrm{C}\right)$ & 780 & 68 \\
Generator efficiency & 0.97 & 0.97 \\
\hline
\end{tabular}




\subsection{Fuel Reforming}

Although it has been shown that direct cracking of hydrocarbons in SOFCs is possible with internal reforming, thermal shocks due to endothermic reactions and its effect on SOFC materials becomes a limiting factor. For small-scale SOFC applications, fuel reforming and adequate preheating of inlet flows must be done in an efficient manner. In the current investigation, a Catalytic Partial Oxidation (CPO) reactor was selected because of its rapid kinetics and its exothermic operation nature. When compared to an Adiabatic Steam Reformer (ASR), the CPO provides better start-up and transient responses and reduces the heat input to the fuel stream, both of which are of significant importance in small-scale power plants. For the pre-reformer, the fuel inlet temperature must be lower than $400{ }^{\circ} \mathrm{C}$ and the outlet should be over $500{ }^{\circ} \mathrm{C}$. This is to avoid carbon coking and achieving certain pre-reforming of hydrocarbons. In the abovementioned coniguration for NG, waste heat from the anode exhaust provides preheated fuel temperatures of $300{ }^{\circ} \mathrm{C}$ or higher for the $\mathrm{CPO}$ reactor.

The outlet temperature of the stream is restricted to $550{ }^{\circ} \mathrm{C}$ for a specific $\mathrm{O} / \mathrm{C}$ ratio. Therefore, an additional heat exchanger for fuel preheating is introduced before the SOFC. Conversely, systems with CPO pre-reformers do not need additional fuel preheating if the $\mathrm{O} / \mathrm{C}$ ratio is maintained above 1 . For DME, ethanol and methanol, a methanator is used, which inadvertently operates like an ASR. The off-fuel is partially recycled and mixed with the incoming fuel. Inlet fuel temperatures and off-fuel recirculation depend on the $\mathrm{O} / \mathrm{C}$ ratio in reformer. Unlike ASR, the reactions for DME and ethanol in the methanator are exothermic. In order to avoid the occurrence of carbon coking, a specific $\mathrm{O} / \mathrm{C}$ ratio value is selected for each fuel; 1.7 for NG and 1.5 for DME, ethanol and methanol. Since the off-fuel includes $\mathrm{CO}_{2}, \mathrm{H}_{2}$ and $\mathrm{CO}$ in addition to $\mathrm{H}_{2} \mathrm{O},(\mathrm{H}+\mathrm{O}) / \mathrm{C}$ should be considered instead of S/C [35]. However, this is not considered in this study.

\subsection{Hydrogen Separation}

For a PEFC, pure hydrogen is needed and therefore one of the key aspects of this study is the extraction of hydrogen from the off-fuel stream and its utilization in the PEFC. The depleted fuel from the SOFC contains a fraction of usable fuel, so the $\mathrm{H}_{2}$ production process must be efficient and effective. In this section, we discuss some methods of purifying the off-fuel for $\mathrm{H}_{2}$ separation. Two different configurations can be adapted for a hydrogen extraction system. One is producing hydrogen using the excess heat of an SOFC module and the exhaust gas with an extra reformer operated independently. Another is extracting hydrogen directly from the off-fuel by purifying the off-fuel.

The former method can further be classified into pressure swing adsorption (PSA), temperature swing adsorption (TSA), $\mathrm{CO}_{2}$ absorber, and a membrane reformer. PSA is a mature technique and it is easy to adapt the PSA system to the present SOFC and hydrogen production system. In this process, the reformed gas first passes through the shift converter and most of $\mathrm{CO}$ is converted there to $\mathrm{H}_{2}$ in the presence of water. Then $\mathrm{CO}$ and $\mathrm{CO}_{2}$ are adsorbed at the PSA and only $\mathrm{H}_{2}$ is collected. In TSA systems, by swinging the temperature, $\mathrm{CO}$ and $\mathrm{CO}_{2}$ can be removed from the off-fuel. $\mathrm{CO}_{2}$ absorbents are another way of purifying the fuel once $\mathrm{CO}$ is converted into $\mathrm{CO}_{2}$ in the water shift reactors. These materials can absorb and desorb $\mathrm{CO}_{2}$ reversibly above and below a certain temperature. A more effective way for purifying the reformed gas is using a membrane reformer. Selective removal of 
hydrogen in a membrane reformer can reduce the reforming temperature compared with conventional processes [11]. The advantage of using the off-fuel purifying system is that the configuration of the system can be simple. One more merit is that it is not necessary to pay attention to the reformer temperature. Here, the hydrogen purifying system is selected for the sake of simplicity.

\section{Results and Discussion}

The presented models were simulated in a two-step approach. First, simulations for the SOFC plant were conducted using NG, DME, ethanol and methanol as fuels and then calculations for complete hybrid plant (including PEFC as bottoming cycle) were carried out. It is important to mention here that net power output of the SOFC plant was affixed at $10 \mathrm{~kW}$ for all the fuels. All power inputs and outputs, material flows, heat losses and heat sources were balanced in the simulations making the modelled plants thermally self-sustainable i.e., no extra heat or fuel was needed. The fuel is fed only to the SOFC cycle. Since the PEFC extracts fuel from the SOFC exhaust stream, the fuel feed remains the same for both the cases (SOFC only, and hybrid plant simulations). Some vital results are presented and discussed below. Main calculated parameters are shown in Table 2.

Table 2. Calculated parameters for the hybrid plant.

\begin{tabular}{ccccc}
\hline Parameter & NG & DME & Ethanol & Methanol \\
\hline Fuel mass flow, $(\mathrm{kg} / \mathrm{h})$ & 1.48 & 2.70 & 2.67 & 3.77 \\
$\mathrm{H}_{2}$ extracted from SOFC off-fuel, $(\mathrm{kg} / \mathrm{h})$ & 0.05 & 0.094 & 0.093 & 0.102 \\
SOFC air compressor mass flow, $(\mathrm{kg} / \mathrm{h})$ & 122.1 & 153.7 & 133.3 & 137.3 \\
PEFC air compressor mass flow, $(\mathrm{kg} / \mathrm{h})$ & 3.12 & 5.61 & 5.55 & 6.07 \\
Catalytic burner temperature, $\left({ }^{\circ} \mathrm{C}\right)$ & 788 & 800 & 801 & 800 \\
ASR/Methanator inlet temperature, $\left({ }^{\circ} \mathrm{C}\right)$ & 535 & 458 & 439 & 341 \\
ASR/Methanator outlet temperature, $\left({ }^{\circ} \mathrm{C}\right)$ & 469 & 546 & 504 & 545 \\
Fuel recirculated to methanator, $(\%)$ & 49 & 40.3 & 40.3 & 20.6 \\
SOFC off-gas temperature, $\left({ }^{\circ} \mathrm{C}\right)$ & 214 & 232 & 235 & 242 \\
SOFC Air/fuel ratio & 82.6 & 53.6 & 47.0 & 35.3 \\
PEFC Air/fuel ratio & 60.2 & 59.6 & 59.6 & 59.6 \\
\hline
\end{tabular}

One of the observable differences is that NG uses more air than any other fuel and has the highest air/fuel ratio. On the other hand, the least amount of air is compressed for SOFC when ethanol is used as a fuel. This is due to the fact that reformed-ethanol has high levels of methane $\left(\mathrm{CH}_{4}\right)$ which lead to more internal reforming (endothermic reactions) in SOFC when compared to other fuels and consequently, less air is needed to cool down the stack. Moreover, in contrast to NG, higher percentages of water in the reformed ethanol promote endothermic reforming in the fuel cell. It can also be observed that the methanator temperature is the lowest for ethanol. Around $40 \%$ of SOFC off-fuel has to be recirculated for DME and ethanol, whereas methanol requires $20 \%$ of off-fuel recycling for methanation at the specified $\mathrm{O} / \mathrm{C}$ ratio of 1.5 . For $\mathrm{NG}$, around $50 \%$ of off-fuel recycled into the ASR. 


\subsection{System Efficiencies}

The plants' net powers and thermal efficiencies (based on LHV, lower heating value) are shown in Table 3. An individual SOFC plant with NG as fuel has the highest of the three thermal efficiencies at $53.1 \%$ (Table 4). DME, ethanol and methanol display efficiencies of $46.3 \%, 50.3 \%$ and $47.9 \%$, respectively, when used as fuels. The power output, as mentioned above has been fixed to $10 \mathrm{~kW}$ for all the cases. For a hybrid plant, these fuels show similar trends. However, PEFC power output for NG is somewhat lower than the others. The reason being that lesser concentrations of $\mathrm{H}_{2}$ are present in the NG off-fuel that is extracted for the PEFC cycle. The off-fuel streams for DME and ethanol have almost the same levels of $\mathrm{H}_{2}$, while methanol has highest $\mathrm{H}_{2}$ levels and therefore high PEFC power output. The thermal efficiencies for PEFC cycle for all fuels are similar at around $47 \%$.

Table 3. Net power and efficiencies for SOFC-only plant.

\begin{tabular}{ccccc}
\hline Parameter & NG & DME & Ethanol & Methanol \\
\hline Net power output, $(\mathrm{kW})$ & 10 & 10 & 10 & 10 \\
Thermal efficiency of plant, (LHV) & 0.531 & 0.463 & 0.503 & 0.479 \\
\hline
\end{tabular}

Table 4. Net power and efficiencies of the plants.

\begin{tabular}{ccccc}
\hline Parameter & NG & DME & Ethanol & Methanol \\
\hline Net power output, $(\mathrm{kW})$ & 10.79 & 11.46 & 11.46 & 11.6 \\
Output power from SOFC cycle, $(\mathrm{kW})$ & 10 & 10 & 10 & 10 \\
Output power from PEFC cycle, $(\mathrm{kW})$ & 0.79 & 1.46 & 1.46 & 1.6 \\
Thermal efficiency of SOFC cycle, $(\mathrm{LHV})$ & 0.531 & 0.435 & 0.474 & 0.465 \\
Thermal efficiency of PEFC cycle, (LHV) & 0.47 & 0.469 & 0.469 & 0.468 \\
Thermal efficiency of plant, (LHV) & 0.574 & 0.50 & 0.543 & 0.539 \\
Increase in thermal efficiency of plant, $(\%)$ & 8 & 7.8 & 7.9 & 12.5 \\
\hline
\end{tabular}

\subsection{Effect of Utilization Factor}

One of the key issues in fuel cells is the fuel utilization factor and the operational strategies associated with it. Simulations show that plant efficiencies observe parabolic characteristics with respect to the $U_{F}$. In Figure 2, it can be seen that thermal efficiencies for all investigated fuels tend to rise as the SOFC $U_{F}$ increases from 50\% and reaches the maximum. Efficiencies decrease when the $U_{F}$ approaches $100 \%$. In the present study, utilization factors of $80 \%$ and $62 \%$ are selected for the SOFC and PEFC, respectively. High utilization factor ensures the use of a smaller number of stacks and thereby less associated costs, since the cost of SOFC stacks is dominant. To compromise between cost and plant efficiency the utilization factor for SOFC is assumed to be $80 \%$. For PEFC only one stack is used, which implies that the connection between its cost and its utilization factor is diminished. This in turn provides the liberty of choosing the utilization factor for the PEFC stack. It is evident from Figure 3 that the SOFC $U_{F}$ has a substantial effect on overall plant efficiency and net power as compared to the PEFC $U_{F}$ effect. This is due to the fact that SOFC produces around $80 \%-90 \%$ of the total plant power. 
Figure 2. Plant efficiencies for different fuels with respect to SOFC utilization factor.

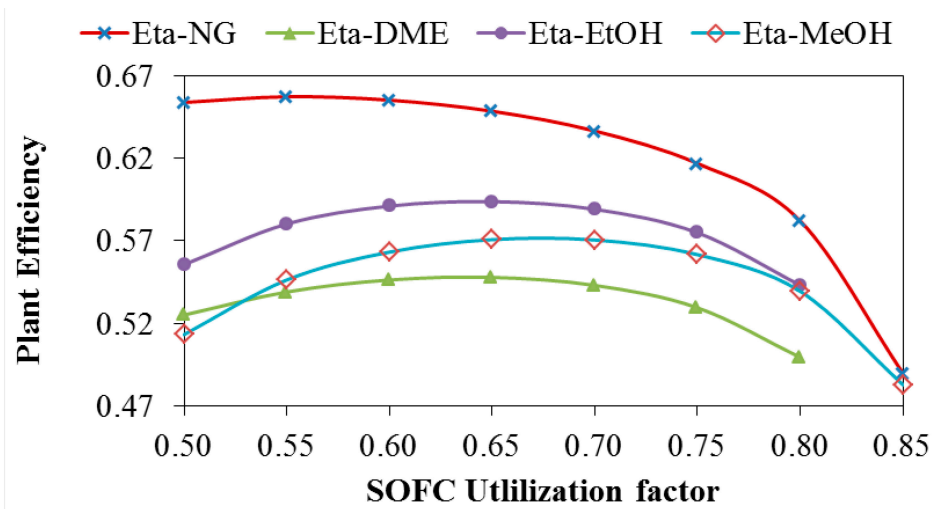

Figure 3. Effect of fuel utilization factors on plant power and efficiency, (a) Changing SOFC $U_{F}$; (b) Changing PEFC $U_{F}$.

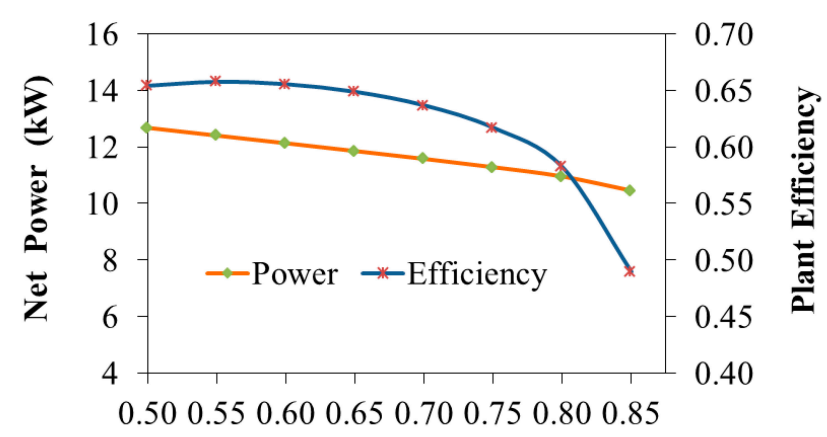

SOFC UF for NG

(a)

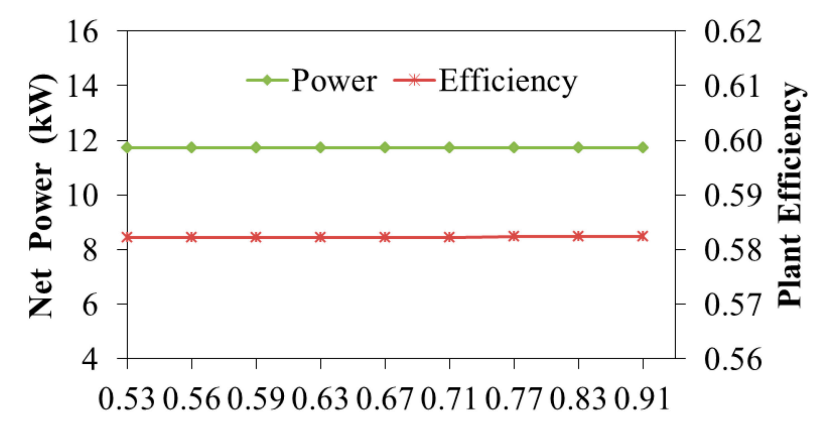

PEFC UF for NG

(b)

\subsection{Effect of SOFC Operating Conditions}

Simulations using all three fuels revealed similar results in the analyses of the SOFC operating conditions and their effect on the hybrid plant. Here, some results for NG are presented. Generally, high pressures in fuel cells enhance their performance but this improvement comes at the expense of some power. Figure 4a shows the effect of SOFC pressure on the plant's efficiency and power consumption of the air compressor. It can be observed that the system efficiency decreases by $10 \%$, when the operating pressure of SOFC is increased to 1.6 bar. This is due to the fact that power consumption of air compressor is increased four-fold (Figure 4b). Although, there is some reduction in the consumption of the PEFC hydrogen pump, its effect on the SOFC air compressor effect is minimal. 
Fuel cell operating temperature positively affects the change in Gibbs free energy of the reaction, $\Delta G_{\mathrm{f}}{ }^{0}$ which has a direct relation with the standard-state reversible voltage. The result is an increase in net power output. However, it is seen in Figure $5 \mathrm{a}$ that the thermal efficiency of the plant decreases. As the operating temperature increases, the difference between SOFC inlet and outlet streams becomes large. In order to sustain the operating temperatures, additional fuel is needed, thereby increasing the fuel intake. Figure $5 \mathrm{~b}$ displays the increase in fuel consumption with respect to SOFC operating temperatures.

Figure 4. (a) Thermal efficiency and plant net power as a function of SOFC operating pressure with NG as fuel; (b) Corresponding power consumption of air compressor.

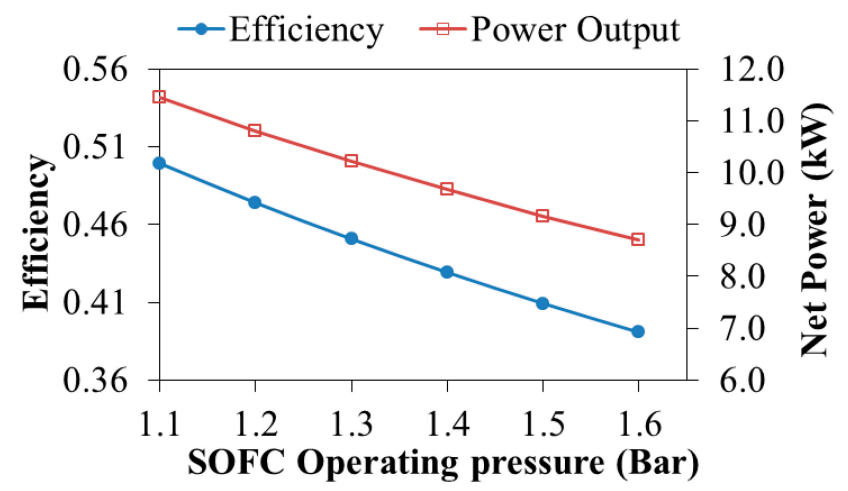

(a)

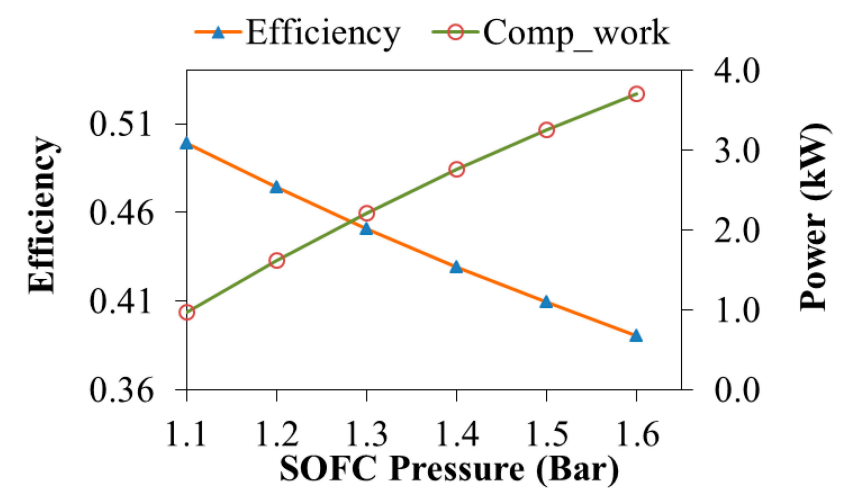

(b)

Figure 5. Effect of SOFC operating temperatures on the hybrid plant, (a) Fuel consumption and efficiency changes with respect to operating temperature; (b) Net power output and efficiency as a function of stack operating temperatures.

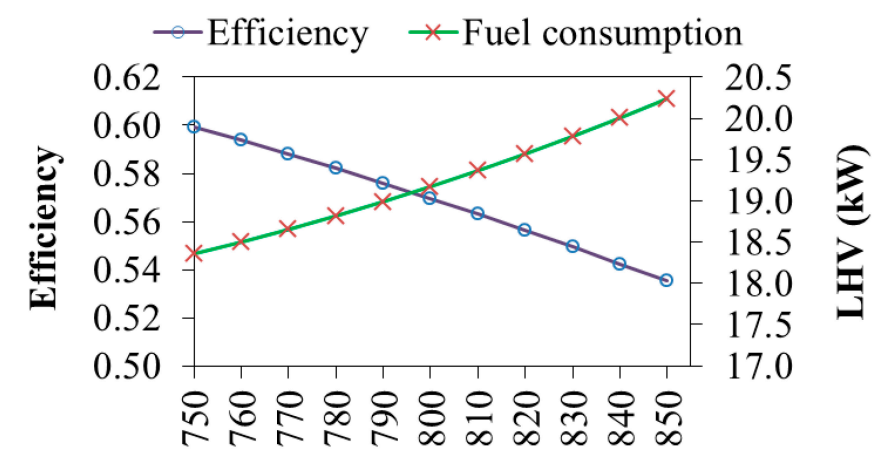

SOFC Op. temp $\left({ }^{\circ} \mathrm{C}\right)$

(a) 
Figure 5. Cont.

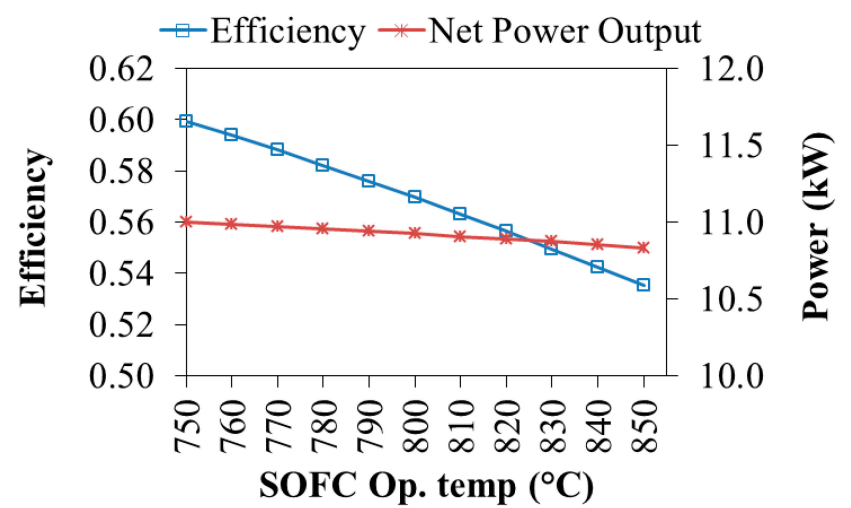

(b)

\subsection{Effect of PEFC Operating Conditions}

Here again, due to similarity in trends, only results for NG are presented. In theory, the operating conditions of the PEFC effect should be same as that of the SOFC. Since, in our proposed system, PEFC is the bottom cycle and produces only a fraction of the total power, its effect on the final output of the hybrid plant is almost negligible. Figure 6a,b show the fact that changes in the PEFC operating temperature and pressure almost have an unnoticeable impact on plant efficiency and net power production.

Figure 6. Effect of PEFC operating conditions on the hybrid plant, (a) Net power and efficiency changes with respect to operating pressure; (b) Net power output and efficiency as a function of PEFC operating temperatures.

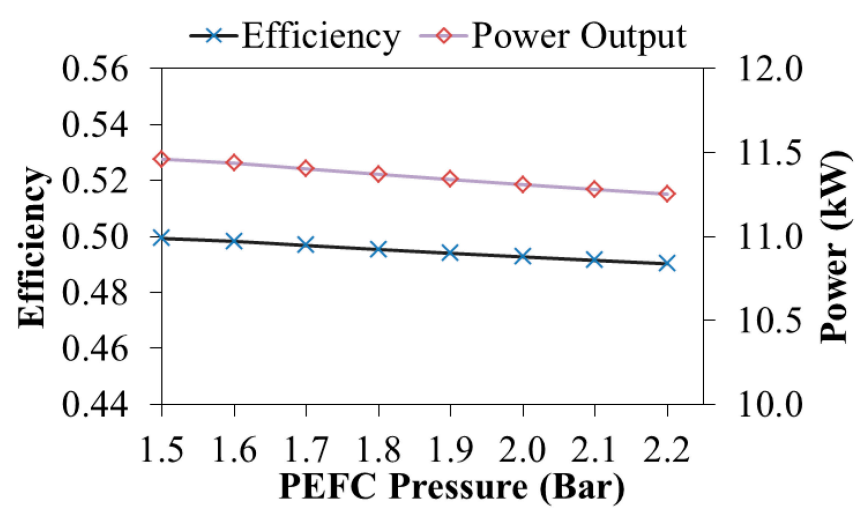

(a)

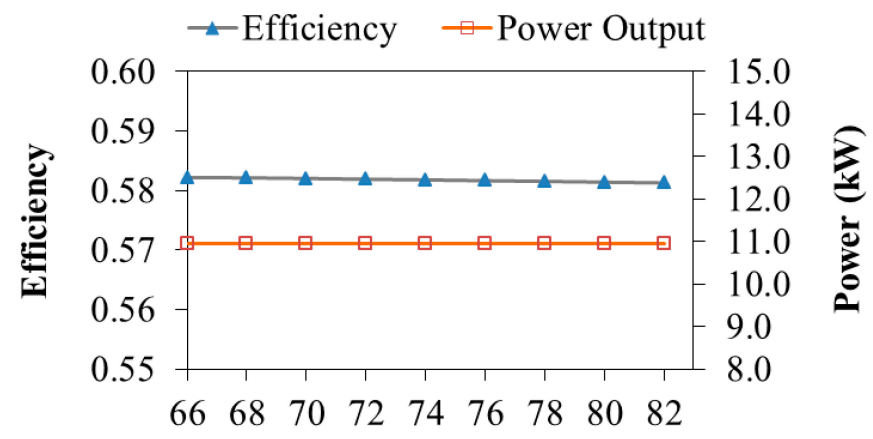

PEFC Op. Temp $\left({ }^{\circ} \mathrm{C}\right)$

(b) 


\subsection{Effect of O/C-Ratio on Reformer and Methanator}

The working principle of a methanator is similar to that of a steam reformer as it utilizes steam to crack higher hydrocarbons. The steam is supplied t by recirculating some portion the SOFC off-fuel and mixing it into the fuel stream. The $\mathrm{O} / \mathrm{C}$ ratios determine the amount of steam to be recirculated and also the inlet temperatures of the methanator. Increasing $\mathrm{O} / \mathrm{C}$ ratios lower the thermal efficiency of the plant, which can be seen in Figure 7. This decrease is due to the collaborative effort of many small factors such as increase in air and fuel mass flows, and compressor consumptions, etc. However, the major contribution occurs in the SOFC itself. High $\mathrm{O} / \mathrm{C}$ ratios and inlet temperatures result in low production of $\mathrm{CH}_{4}$ in the ASR/methanator, thereby requiring more fuel and air in the SOFC for thermal sustainability. On the other hand, although lowering $\mathrm{O} / \mathrm{C}$ ratios in the methanator increases the overall efficiency of the system, they are limited to a certain level for each fuel in order to avoid carbon formation and thereby ensuring stable plant operations. For examples effect of $\mathrm{O} / \mathrm{C}$ ratio on efficiency and net power for DME and Ethanol are shown in Figure 8a,b.

Figure 7. Plant efficiencies with respect to $\mathrm{O} / \mathrm{C}$ ratios in reformer/methanator for different fuels.

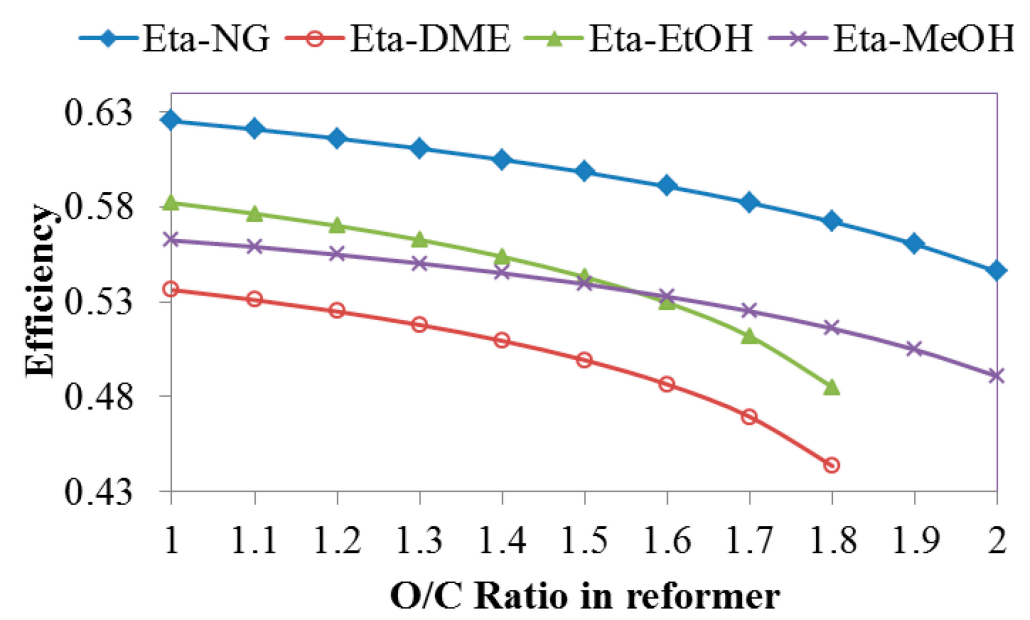

Figure 8. Effect of $\mathrm{O} / \mathrm{C}$ ratios, (a) Thermal efficiencies and off-fuel recirculation in methanator for DME; (b) Fuel consumption and net power output as a function of $\mathrm{O} / \mathrm{C}$ ratio in methanator for ethanol.

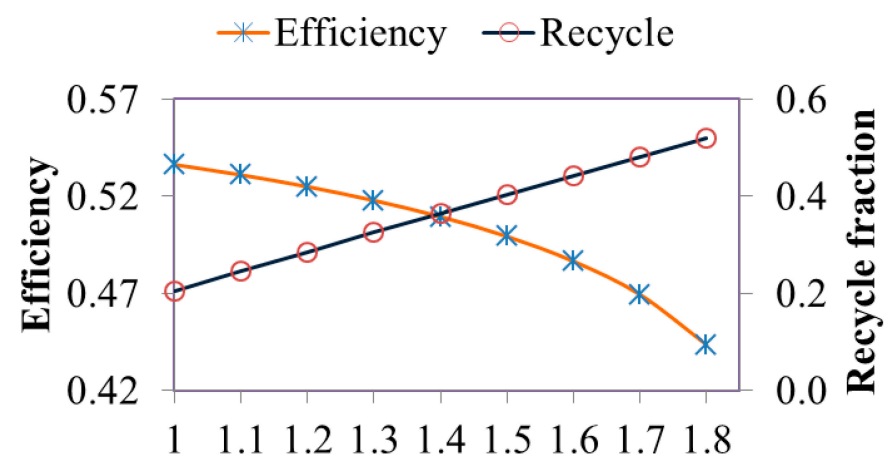

O/C Ratio for DME

(a) 
Figure 8. Cont.

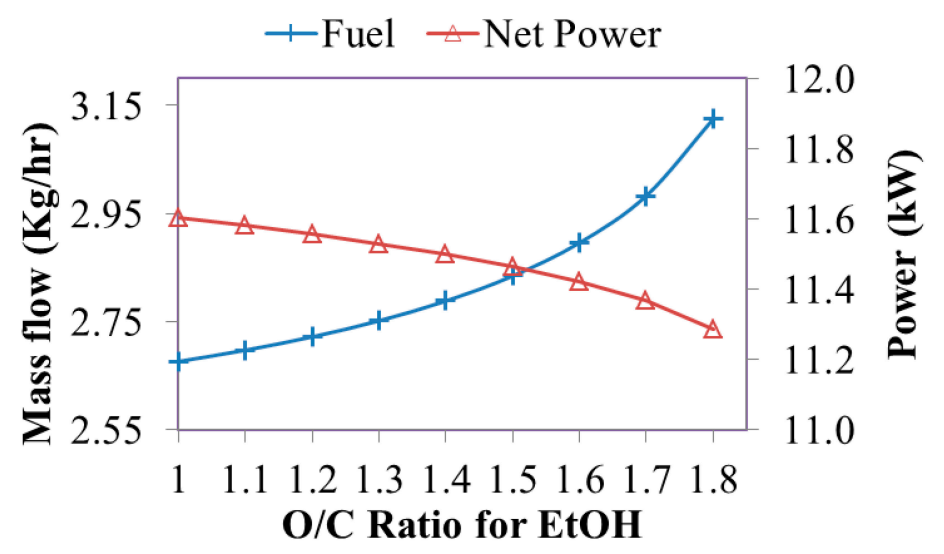

(b)

\subsection{Effect of Off-Fuel Recirculation in Methanator}

Simulations for all fuels give analogous results. Fuel preheating does not affect either the power or the efficiency of the plant. Figure 9a indicates no change in thermal efficiency with increasing fuel preheating temperatures for DME. However, the inlet and outlet temperatures of the methanator change with respect to fuel preheating. It can be observed in Figure $9 \mathrm{~b}$ that the methanator inlet temperature for methanol is reduced to $260{ }^{\circ} \mathrm{C}$ from $360{ }^{\circ} \mathrm{C}$, when fuel preheating is lowered from $250{ }^{\circ} \mathrm{C}$ to none, whereas, DME and ethanol show only slight deviations in the methanator inlet and outlet temperatures with respect to fuel preheating. Therefore, one of the possible presumptions of this study can be the elimination of the fuel preheater, making the plant more compact when designing systems running on DME and ethanol.

Figure 9. Fuel preheating effect, (a) Plant efficiency and net power as function of DME preheating temperature; (b) Inlet and outlet temperatures in reformer with respect to fuel preheating temperature.

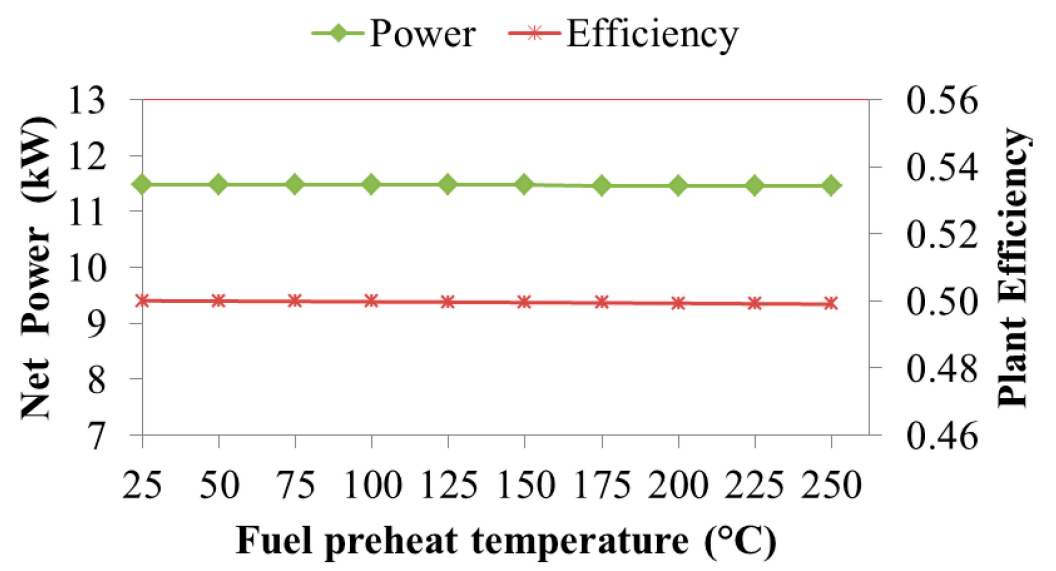

(a) 
Figure 9. Cont.

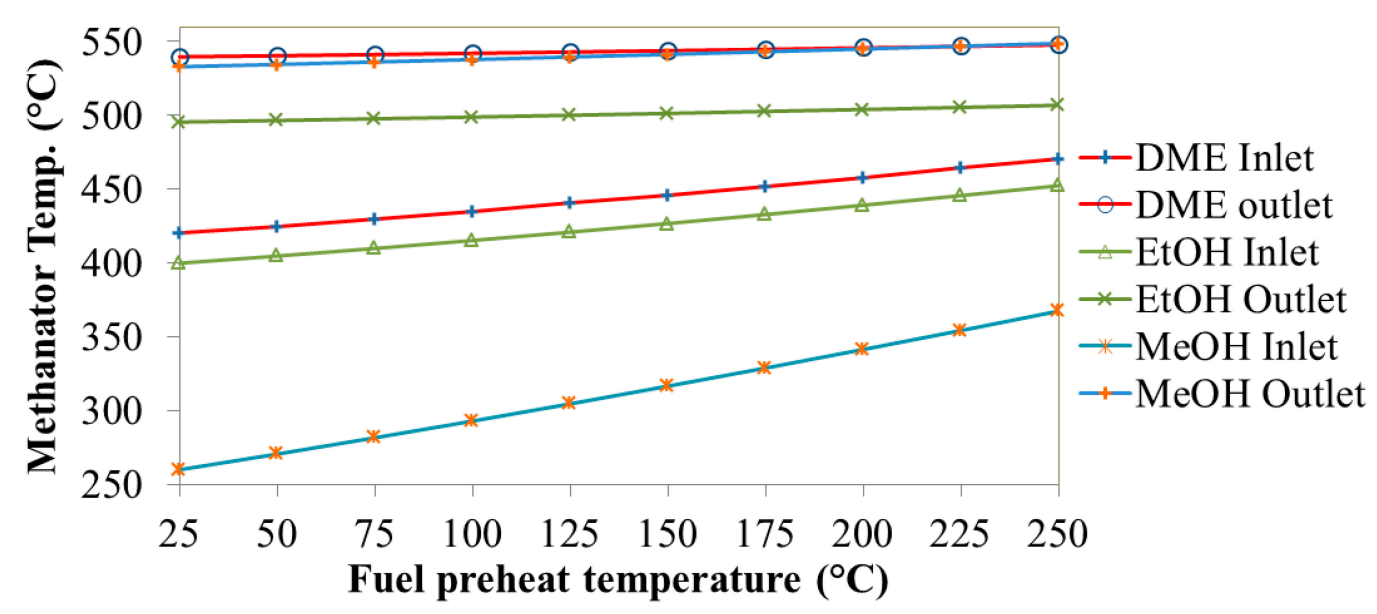

(b)

\section{Conclusions}

An idea for a hybrid combined SOFC-PEFC plant is proposed and analysed. The plant configuration is of series in nature with SOFC as topping and a PEFC bottoming cycle. One of the key objectives is to extract $\mathrm{H}_{2}$ from the SOFC off-fuel and feed it to the PEFC cycle. NG, DME and ethanol were used for system simulations. Preliminary results indicate that plant using ethanol has the highest system efficiency. Moreover, it has been identified that addition of the PEFC cycle increases the efficiency of the hybrid system when compared to a SOFC only plant and reached approximately $57 \%$ in at least one case. The efficiency rise is around $8 \%$ for NG, $9 \%$ for DME and ethanol, and more than $12 \%$ when methanol is used as a fuel, as more $\mathrm{H}_{2}$ was available for PEFC when methanol was used as fuel and the least amount of anode off-fuel recirculation was needed, therefore a higher percentage of efficiency increment was reported than in the other cases.

The operating conditions for SOFC have a significant impact on the plant operations whereas, PEFC operating conditions do not have any considerable influence on the system. Lower $\mathrm{O} / \mathrm{C}$ ratios tend to increase overall plant efficiency; however they cannot be regulated to below a certain limit in order to avoid carbon formation hazards. Another deduction worth mentioning is that when designing a system for DME or ethanol, the fuel preheater can be eliminated, so these systems will eventually be more compact when compared to other configurations.

\section{Author Contributions}

Authors equally contributed in preparing this manuscript.

\section{Conflicts of Interest}

The authors declare no conflict of interest. 


\section{References}

1. Rokni, M. Thermodynamic analysis of an integrated solid oxide fuel cell cycle with a rankine cycle. Energy Convers. Manag. 2010, 51, 2724-2732.

2. Song, C. Fuel processing for low-temperature and high-temperature fuel cells - Challenges, and opportunities for sustainable development in the 21st century. Catal. Today 2002, 77, 17-49.

3. Rokni, M. Plant characteristics of an integrated solid oxide fuel cell cycle and a steam cycle. Energy 2010, 35, 4691-4699.

4. Chan, S.H.; Ho, H.K.; Tian, Y. Multi-level modeling of SOFC-gas turbine hybrid system. Int. J. Hydrog. Energy 2003, 28, 889-900.

5. Bang-Møller, C.; Rokni, M. Thermodynamic performance study of biomass gasification, solid oxide fuel cell and micro gas turbine hybrid systems. Energy Convers. Manag. 2010, 51, 2330-2339.

6. Rokni, M. Thermodynamic analysis of SOFC (solid oxide fuel cell)—Stirling hybrid plants using alternative fuels. Energy 2013, 61, 87-97.

7. Chen, L.; Gao, S.; Zhang, H. Performance analysis and multi-objective optimization of an irreversible solid oxide fuel cell-stirling heat engine hybrid system. Int. J. Electrochem. Sci. 2013, 8, 10772-10787.

8. Dicks, A.L.; Fellows, R.G.; Martin Mescal, C.; Seymour, C. A study of SOFC-PEM hybrid systems. J. Power Sources 2000, 86, 501-506.

9. Vollmar, H.E.; Maier, C.U.; Nölscher, C.; Merklein, T.; Poppinger, M. Innovative concepts for the coproduction of electricity and syngas with solid oxide fuel cells. J. Power Sources 2000, 86, 90-97.

10. Subramanyan, K.; Diwekar, U.M. Optimizing model complexity with application to fuel cell based power systems. Chem. Eng. Process. 2007, 46, 1116-1128.

11. Yakabe, H.; Yoshida, H.; Amaha, S. A combined system of an SOFC and PEFCs. ECS Trans. 2009, 25, 301-312.

12. Yokoo, M.; Take, T. Simulation analysis of a system combining solid oxide and polymer electrolyte fuel cells. J. Power Sources 2004, 137, 206-215.

13. Yokoo, M.; Watanabe, K.; Arakawa, M.; Yamazaki, Y. Numerical evaluation of a parallel fuel feeding SOFC-PEFC system using seal-less planar SOFC stack. J. Power Sources 2006, 153, $18-28$.

14. Yokoo, M.; Watanabe, K.; Arakawa, M.; Yamazaki, Y. The effect of fuel feeding method on performance of SOFC-PEFC system. J. Power Sources 2006, 159, 836-845.

15. Petersen, T.F.; Houbak, N.; Elmegaard, B. A zero-dimensional model of a 2 nd generation planar SOFC using calibrated parameters. Int. J. Thermodyn. 2006, 9, 161-169.

16. Rokni, M. Biomass gasification integrated with a solid oxide fuel cell and Stirling engine. Energy 2014, 2014, doi:10.1016/j.energy.2014.01.078.

17. Spiegel, C. Designing and Building Fuel Cells; McGraw-Hill: New York, NY, USA, 2007; pp. 87-100. 
18. Keegan, K.M.; Chick, L.A.; Recknagle, K.; Simner, S.P.; Diebler, J. Analysis of a planar solid oxide fuel cell based automotive auxiliary power unit. SAE Tech. Paper Ser. 2002, 2002, doi:10.4271/2002-01-0413.

19. Achenbach, E. Three-dimensional and time-dependent simulation of a planar solid oxide fuel cell stack. Power Sources 1994, 49, 333-348.

20. Kim, J.W.; Virkar, A.V. The effect of anode thickness on the performance of anode-supported solid oxide fuel cells. Solid Oxide Fuel Cells (SOFC VI) 1999, 99, 830-839.

21. Smith, J.M.; van Ness, H.C.; Abbott, M.M. Introduction to Chemical Engineering Thermodynamics; McGraw-Hill: Boston, MA, USA, 2005; p. 817.

22. Leonide A.; Apel, Y.; Ivers-Tiffée, E. SOFC modeling and parameter identification by means of impedance spectroscopy. ECS Trans. 2009, 19, 81-109.

23. Peksen, M.; Al-Masri, A.; Peters, R.; Blum, L.; Stolten, D. Recent developments of 3D coupled multiphysics SOFC modelling at Forschungszentrum Jülich. ECS Trans. 2013, 57, 2537-2541.

24. Milewski, J. A mathematical model of SOFC: A proposal. Fuel Cells 2012, 12, 709-721.

25. Mark9 SSL ${ }^{\text {TM }}$. Product Manual and Integration Guide; Ballard Power Systems Inc.: Burnaby, BC, Canada, 2008.

26. Hosseinzadeh, E.; Rokni, M. Development and validation of a simple analytical model of the proton exchange membrane fuel cell (PEMFC) in a fork-lift truck power system. Int. J. Green Energy 2013, 10, 523-543.

27. Springer, T.E.; Zawodzinski, T.A.; Gottesfeld, S. Polymer electrolyte fuel-cell model. J. Electrochem. Soc. 1991, 138, 2334-2342.

28. Haji, S. Analytical modeling of PEM fuel cell I-V curve. J. Renew. Energy 2011, 36, 451-458.

29. Martemianov, S.; Bograchev, D.; Grandidier, J.C.; Kadjo, J.J. Thermo-mechanical phenomena in PEM fuel cells. Energy Res. 2010, 34, 635-642.

30. Carmo, M.; Fritz, D.L.; Mergel, J.; Stolten, D. A comprehensive review on PEM water electrolysis. Hydrog. Energy 2013, 38, 4901-4934.

31. Rokni, M. Thermodynamic investigation of an integrated gasification plant with solid oxide fuel cell and steam cycles. Green 2012, 2, 71-86.

32. Rabbani, A.; Rokni, M. Dynamic characteristics of an automotive fuel cell system for transitory load changes. Sustain. Energy Technol. Assess. 2013, 1, 34-43.

33. Rabbani, A.; Rokni, M.; Hosseinzadeh, E.; Mortensen, H.H. The start-up analysis of a PEM fuel cell system in vehicles. Int. J. Green Energy 2014, 11, 91-111.

34. Rabbani, A.; Rokni, M. Effect of nitrogen crossover on purging strategy in PEM fuel cell systems. Appl. Energy 2013, 111, 1061-1070.

35. Sasaki, K.; Teraoka, Y. Equilibria in fuel cell gases II. The C-H-O ternary diagrams. J. Electrochem. Soc. 2003, 150, A885-A888.

(C) 2014 by the authors; licensee MDPI, Basel, Switzerland. This article is an open access article distributed under the terms and conditions of the Creative Commons Attribution license (http://creativecommons.org/licenses/by/3.0/). 